\title{
Determination of Selected Physical and Chemical Characteristics of Neem Seed Husk Ash Blended Cement
}

\author{
${ }^{1}$ Raheem, A. A. and ${ }^{2}$ Ibiwoye, E. O. \\ ${ }^{1}$ Department of Civil Engineering, Ladoke Akintola University of Technology, Ogbomoso, Nigeria. \\ ${ }^{2}$ Department of Civil Engineering, Kwara State Polytechnic, Ilorin, Nigeria. \\ Corresponding E-mail: aaraheem@lautech.edu.ng
}

\begin{abstract}
Neem tree (Azadirachtaindica) is a tropical evergreen tree scattered all over the country, hence its availability can add to the list of materials used as pozzolan. This study investigated the characteristics of Neem Seed Husk Ash (NSHA) blended cement produced in the factory. Neem fruit was collected from Olooru town and Ilorin metropolis in Kwara State Nigeria, after collection, the seed was removed with the use of Decorticator huskers, sun dried for 3 days to reduce its moisture content and burnt in a furnace at a temperature of $650 \pm 50{ }^{\circ} \mathrm{C}$. The chemical composition $\left(\mathrm{SiO}_{2}, \mathrm{Al}_{2} \mathrm{O}_{3}\right.$ and $\left.\mathrm{Fe}_{2} \mathrm{O}_{3}\right)$ and physical characteristics were determined. Blended cement was produced by intergrinding 5, 10, 15, 20, 25, 30, 35, 40, 45 and $50 \%$ by weight of NSHA with Ordinary Portland Cement (OPC) clinker and gypsum. OPC without NSHA served as the control. The blended cements produced were analyzed for chemical composition using X-Ray Flourescence Analyser (XRF). The physico-mechanical properties of blended cement (fineness, initial and final setting time, heat of hydration) produced was examined.

The total percentage of $\mathrm{SiO}_{2}, \mathrm{Al}_{2} \mathrm{O}_{3}$ and $\mathrm{Fe}_{2} \mathrm{O}_{3}$ for NSHA is $75.35 \%$. Factory produced NSHA - blended cement is suitable as it satisfied the maximum requirement of 375 minutes for final setting time and 45 minutes minimum initial setting time, hence it can be used for construction work where strength is not a priority
\end{abstract}

Keywords: NSHA, XRF, Setting time, consistency, hydration, pozzolan

\section{Introduction}

Growth in human population over the last five decades has doubled from 3 to 6 billion and it is expected to grow more in years to come (Ngab, 2002). To serve the needs and changes, large amount of materials are needed for the construction of houses, office buildings, roads and other infrastructures required for decent living. One of the constituent materials in making concrete is cement. The demand for cement is increasing as a result of population growth. Thus, effort to find alternative materials which must be inexpensive, readily available in large quantity and require little energy to produce has to be undertaken. Nowadays, the current trend is to use by - products or agricultural residues to partially replace cement in making

According to Olusola and Adesanya (2004) it is of great importance to make provision for availability and accessibility to building materials and decent housing for the teaming populace of the world, especially those in developing countries. It is evident that building materials are getting outside the reach of the teeming populace who are extremely living below the poverty line. Hence, the need to find alternative local building materials that can serve the same purpose in building construction industries both in the urban and rural. This study is focused on Portland cement, known to be one of the most commonly used building materials. Concrete as a construction material is one of the most commonly used man - made materials and it is believed that the consumption of this material is of the order of ten billion tonnes per year, very close to the total consumption of water (Kartini et al., 2006).

One of the constituent materials in making concrete is cement. The demand for cement is increasing as a result of population growth. Thus, effort to find alternative materials which must be inexpensive, readily available in large quantity and require little energy to produce has to be undertaken. Nowadays, the current trend is to use by - products or agricultural residues to partially replace cement in making concrete. 
The increasing concern for environmental protection, energy conservation with minimal impact on economy has been motivating researchers to identify alternatives for cement in the construction industry. These alternatives should enhance the production of environmentally safe, stable, durable and low cost construction materials. It is evidently clear that production of cement consumes high energy, reduces natural resources and releases large quantity of greenhouse gases (mostly $\mathrm{CO}_{2}$ ). Illston and Domone (2001) reported that the production of 1 tonne of cement consumes about 4 GJ of energy and needs about 1.7 tonnes of unprocessed raw materials (limestone and shale) which in turn cause environmental degradation and pollution problems. Therefore, concrete technology has focused on other substitutes which can be used as alternatives or can serve as supplement to cement in construction works. From the technological, ecological and economic view points, cement replacement materials occupy an undisputed position in the construction industry. Little quantities of inert fillers have always been acceptable as cement substitutes. The fillers have pozzolanic properties and do not only have technical advantages on concrete, but also empower a larger quantity of cement replacement to be made possible (Khandaker and Anwar, 2003).

According to Day (1990) the usage of pozzolanic materials, some of which are industrial by-products, preserves natural resources that are employed in the production of cement. Neem Seed Husk is a residue that is obtained during industrial processing of Neem Seed to extract oil and produce fertilizer. In producing Neem based fertilizer, extraction of Neem oil is done first, and the resulting cake (which consists of ground seed and husk) is adapted in producing organic based fertilizer while the remnant large quantity of Neem husk usually lay as waste. Neem Seed Husk Ash (NSHA) is produced by burning the Neem seed husk which comes from the Neem tree (Azadirachta indica).

Previous studies showed that many researchers such as Nuruddeen (2014) has worked on thermal analysis of cement paste partially substituted with NSHA. Ramsharath et al., (2017) studied the use of NSHA as replacement for cement. The on-site method was used to replace cement with NSHA. In the study, the workability of NSHA concrete was found to improve from 5 to $10 \%$ replacement in cement without considering blending of NSHA with clinker and gypsum during factory production of cement. Also, Ibiwoye (2015) investigated the use of NSHA as partial replacement for cement in concrete, the on-site method was used to replace cement with NSHA from $5 \%$ to $25 \%$. The study indicated that slump and compacting factor decreased as the NSHA content in the mixture increased for constant water cement ratio. This implies that the concrete becomes less workable (stiff) as the NSHA percentage increases without considering blending of NSHA with clinker and gypsum during factory production of cement Therefore, this study focused on the determination of chemical composition of NSHA as well as selected physical and chemical properties of the blended cements produced at varying percentage replacements of NSHA during the manufacturing process.

\section{Materials and Methods}

\section{Materials}

In the production of NSHA - blended cement, there are many materials that are needed for usage. These materials are discussed in details highlighting their source, usage and method of production.

\section{Neem Seed Husk}

The neem seed husk that was used in this study was collected from Neem Seed Pod, obtained from Neem trees at various locations in Olooru town and Ilorin metropolis, Kwara state. The Neem fruit after collection, the seed was removed with the use of Decorticator huskers, after which it was sun dried to reduce its moisture content and calcinated in a murfle furnace at temperature of about $650{ }^{0} \mathrm{C}$ to produce NSHA. 
Clinker

Ordinary Portland cement clinker (OPC clinker) used for this study was obtained from Lafarge, West Africa Portland Cement Company (WAPCO), Sagamu Plant, Ogun State, Nigeria. The Gypsum that was used to produce the blended cement was also obtained from Lafarge, WAPCO, Sagamu Plant. The gypsum was in granular form with particle size range of 2 to $8 \mathrm{~mm}$ which is suitable to achieve adequate blending of the cement (Shetty, 2005).

\section{Production of NSHA Blended cement}

The production of NSHA blended cement was carried out at Lafarge, (WAPCO) Sagamu Plant, Ogun State, Nigeria. The production process comprised batching, preparation of cement mixture and milling process. The NSHA blended cement was produced by iintergrinding Portland cement clinker with 5\% $50 \%$ NSHA replacement during the cement manufacturing process.

\section{Results and Discussion}

Chemical Composition of Neem Seed Husk Ash (NSHA)

Table 1 is the result of the pozzolanicity test carried out on Neem Seed Husk Ash (NSHA) indicating the average percentage composition of each element. The chemical constituents include Aluminium Oxide $\left(\mathrm{Al}_{2} \mathrm{O}_{3}\right)$, Silica Oxide $\left(\mathrm{SiO}_{2}\right)$ and Iron Oxide $\left(\mathrm{Fe}_{2} \mathrm{O}_{3}\right)$ amongst others. The combination of these three compounds makes NSHA useful as a pozzolan since it summed up to $75.35 \%$ which is above $70 \%$. Hence, the specification of ASTM C618 for a combined $\mathrm{Al}_{2} \mathrm{O}_{3}+\mathrm{SiO}_{2}+\mathrm{Fe}_{2} \mathrm{O}_{3}$ of $70 \%$ or above is satisfied. This is also established from the research conducted on the use of corn cob ash (CCA), Volcanic Ash (VA), Palm Oil Fuel Ash (POFA) and Rice Husk Ash (RHA) as pozzolan, (Adesanya and Raheem, 2009; Khandaker and Anwar, 2003 and Fetra Venny, 2011).

Table 1: Chemical Properties of Neem Seed Husk Ash (NSHA)

\begin{tabular}{lllll}
\hline Constituents & $\begin{array}{c}\text { Sample } 1 \\
(\%)\end{array}$ & $\begin{array}{c}\text { Sample } 2 \\
(\%)\end{array}$ & $\begin{array}{c}\text { Sample 3 } \\
(\%)\end{array}$ & $\begin{array}{c}\text { Average } \\
(\%)\end{array}$ \\
\hline $\mathrm{SiO}_{2}$ & 69.14 & 69.13 & 69.16 & 69.15 \\
$\mathrm{Al}_{2} \mathrm{O}_{3}$ & 2.94 & 2.96 & 2.94 & 2.95 \\
$\mathrm{Fe}_{2} \mathrm{O}_{3}$ & 3.25 & 3.24 & 3.27 & 3.25 \\
$\mathrm{CaO}$ & 2.75 & 2.77 & 2.76 & 2.76 \\
$\mathrm{MgO}$ & 0.54 & 0.56 & 0.55 & 0.55 \\
$\mathrm{SO}_{3}$ & 0.42 & 0.43 & 0.41 & 0.42 \\
$\mathrm{Na}_{2} \mathrm{O}$ & 0.15 & 0.14 & 0.17 & 0.15 \\
$\mathrm{~K}_{2} \mathrm{O}$ & 15.01 & 15.02 & 15.04 & 15.02 \\
$\mathrm{TiO}_{2}$ & 0.24 & 0.26 & 0.24 & 0.25 \\
$\mathrm{P}_{2} \mathrm{O}_{5}$ & 1.01 & 1.01 & 1.01 & 1.01 \\
$\mathrm{Mn}_{2} \mathrm{O}_{3}$ & 0.04 & 0.04 & 0.05 & 0.04 \\
\hline
\end{tabular}

Chemical Composition of OPC - Clinker

Table 2 is the chemical composition of clinker used in the production of NSHA blended cements. The result shows that the mean value of silica $\left(\mathrm{SiO}_{2}\right)$ and calcium oxide $(\mathrm{CaO})$ contents of OPC-clinker samples were $20.30 \%$ and $65.90 \%$ respectively. These result show a slight reduction in $\mathrm{SiO}_{2}$ and $\mathrm{CaO}$ compared to the values of $22.56 \%$ and 66.54\%) obtained by Adesanya and Raheem (2009b) for $\mathrm{SiO}_{2}$ and $\mathrm{CaO}$ respectively. The minimum ratio of 2.1 for $\mathrm{CaO}: \mathrm{SiO}_{2}$ specified by BS EN 197-1:2000 was satisfied by the OPC - clinker used.

The average values (5.5\% and 3.5\%) of the other main oxides of Portland cement i.e Alumina oxide $\left(\mathrm{Al}_{2} \mathrm{O}_{3}\right)$ and iron oxide $\left(\mathrm{Fe}_{2} \mathrm{O}_{3}\right)$ contents present in OPC-clinker used were slightly higher than the average values (4.4\% and 3.0\%) obtained by Adesanya and Raheem (2009b). The maximum contents of magnesium oxide (MgO), 5.0\% specified by BS 197 -1:2000 was satisfied by the OPC-clinker which has 
$2.0 \% \mathrm{MgO}$. This is in line with the value of $\mathrm{MgO}$ content of $1.82 \%$ obtained by Adesanya and Raheem (2009b). Other minor oxides contents of $\mathrm{SO}_{3}, \mathrm{~K}_{2} \mathrm{O}, \mathrm{Na}_{2} \mathrm{O}, \mathrm{P}_{2} \mathrm{O}_{5}$ are in the range of $0.2 \%-2.2 \%$. All the composition also satisfied the requirements in ASTM C 150:2002 and NIS 439:2000. Thus, the clinker is suitable for cement production.

Table 2: Chemical composition of OPC - clinker

\begin{tabular}{ccccc}
\hline Constituents & $\begin{array}{c}\text { Sample } 1 \\
(\%)\end{array}$ & $\begin{array}{c}\text { Sample } 2 \\
(\%)\end{array}$ & $\begin{array}{c}\text { Sample } 3 \\
(\%)\end{array}$ & $\begin{array}{c}\text { Average } \\
(\%)\end{array}$ \\
\hline $\mathrm{SiO}_{2}$ & 20.22 & 20.25 & 20.45 & 20.30 \\
$\mathrm{Al}_{2} \mathrm{O}_{3}$ & 5.30 & 5.45 & 5.65 & 5.47 \\
$\mathrm{Fe}_{2} \mathrm{O}_{3}$ & 3.43 & 3.26 & 3.72 & 3.47 \\
$\mathrm{CaO}$ & 66.00 & 64.85 & 66.85 & 65.90 \\
$\mathrm{MgO}$ & 2.28 & 1.98 & 1.80 & 2.02 \\
$\mathrm{SO}_{3}$ & 2.14 & 2.14 & 2.23 & 2.17 \\
$\mathrm{Na}_{2} \mathrm{O}$ & 0.15 & 0.15 & 0.15 & 0.15 \\
$\mathrm{~K}_{2} \mathrm{O}$ & 0.29 & 0.32 & 0.23 & 0.28 \\
$\mathrm{P}_{2} \mathrm{O}_{5}$ & 0.17 & 0.13 & 0.21 & 0.17 \\
$\mathrm{LOI}$ & 1.33 & 1.30 & 1.30 & 1.31 \\
$\mathrm{LSF}$ & 95.93 & 95.73 & 96.04 & 95.90 \\
$\mathrm{AR}$ & 1.55 & 1.64 & 1.45 & 1.55 \\
$\mathrm{SR}$ & 2.23 & 2.35 & 2.17 & 2.25 \\
Free lime & 1.11 & 1.05 & 0.94 & 1.03 \\
\hline
\end{tabular}

\section{Chemical Composition of NSHA blended cement}

The chemical compositions of NSHA blended cements produced are as presented in Table 3 . The silica content of the blended cement increased from $20.2 \%$ for $5 \%$ replacement to $20.8 \%$ for $50 \%$ replacement. However, there was a different behaviour with alumina $\left(\mathrm{Al}_{2} \mathrm{O}_{3}\right)$ contents which decreased in percentage content from 5.43 to 3.86 for increase in percentage replacement from 5\% and $50 \%$. Ferric oxide $\left(\mathrm{Fe}_{2} \mathrm{O}_{3}\right)$ content has a similar behavior with Alumina as it decreased from $3.51 \%$ to $1.92 \%$ increase in replacement from 5\% to $50 \%$. It is therefore not the same trend with the results of Adesanya and Raheem (2009b) which reported an increase in the value of ferric oxide from $2 \%$ to $25 \%$. Lea (2005) reported that cement with a higher percentage content of ferric oxide $\left(\mathrm{Fe}_{2} \mathrm{O}_{3}\right)$ is responsible for impacting colour on cement product. Iron oxide may be obtained from laterite association with geological formation (Dabai et al., 2009). The NSHA blended cements produced with all percentage replacements satisfied the requirements for type II and type IIA Portland cement specified by ASTM C 150: 2000.

Furthermore, all the NSHA blended cement produced, have a lower percentage of calcium oxide $(\mathrm{CaO})$ than the control and decreased from 5\% to 50\% replacement. These results are in consonance with the results reported by Adesanya and Raheem (2009b) showing a decrease in the values of calcium oxide from $2 \%$ to $25 \%$. Calcium oxide is responsible for the formation of $\mathrm{C}_{3} \mathrm{~S}\left(3 \mathrm{CaO} . \mathrm{SiO}_{2}\right)$ and $\mathrm{C}_{2} \mathrm{~S}$ $\left(2 \mathrm{CaO} . \mathrm{SiO}_{2}\right)$ in cement as well as all other clinker minerals which are also responsible for the strength in the early or later age of the concrete (Taylor, 2004).

With increase in the percentage of NSHA replacement, more silicate and less alumina, ferric and calcium oxide which are the major oxide compounds $\left(\mathrm{SiO}_{2}, \mathrm{Al}_{2} \mathrm{O}_{3}, \mathrm{Fe}_{2} \mathrm{O}_{3}, \mathrm{CaO}\right)$ present in the blended cement were available to react with the lime produced during hydration of cement to produce additional cementitious products. It could be seen that the magnesia content of all the NSHA blended cements were also of lower values but higher than the control (2.06).

Table 3: Chemical Composition of NSHA blended Cement 


\begin{tabular}{|c|c|c|c|c|c|c|c|c|c|c|c|}
\hline Constituents & Percer & tage $\mathrm{Cc}$ & npositi & $n(\%)$ & & & & & & & \\
\hline & 0 & 5 & 10 & 15 & 20 & 25 & 30 & 35 & 40 & 45 & 50 \\
\hline $\mathrm{SiO}_{2}$ & 20.17 & 20.21 & 20.23 & 20.27 & 20.32 & 20.36 & 20.42 & 20.48 & 20.57 & 20.79 & 20.81 \\
\hline $\mathrm{Al}_{2} \mathrm{O}_{3}$ & 5.43 & 5.41 & 5.32 & 5.22 & 5.01 & 4.78 & 4.65 & 4.53 & 4.51 & 4.32 & 3.86 \\
\hline $\mathrm{Fe}_{2} \mathrm{O}_{3}$ & 3.51 & 3.21 & 3.07 & 2.84 & 2.54 & 2.42 & 2.31 & 2.27 & 2.17 & 2.08 & 1.92 \\
\hline $\mathrm{CaO}$ & 63.57 & 62.76 & 60.56 & 57.87 & 55.78 & 51.32 & 49.45 & 47.65 & 45.45 & 44.32 & 42.48 \\
\hline $\mathrm{MgO}$ & 2.06 & 2.33 & 2.54 & 2.63 & 2.72 & 2.86 & 2.97 & 3.05 & 3.12 & 3.21 & 3.37 \\
\hline $\mathrm{SO}_{3}$ & 2.21 & 2.34 & 2.44 & 2.51 & 2.74 & 2.82 & 2.85 & 2.89 & 2.92 & 3.08 & 3.11 \\
\hline $\mathrm{Na}_{2} \mathrm{O}$ & 0.15 & 0.12 & 0.12 & 0.06 & 0.04 & 0.03 & 0.02 & 0.02 & 0.01 & 0.02 & 0.03 \\
\hline $\mathrm{K}_{2} \mathrm{O}$ & 0.30 & 0.42 & 0.64 & 0.76 & 0.94 & 1.02 & 1.50 & 1.89 & 2.00 & 2.84 & 3.11 \\
\hline $\mathrm{P}_{2} \mathrm{O}_{5}$ & 0.11 & 0.16 & 0.19 & 0.21 & 0.24 & 0.27 & 0.32 & 0.58 & 0.62 & 0.69 & 0.73 \\
\hline Free lime & 1.47 & 1.45 & 1.43 & 1.41 & 1.39 & 1.37 & 1.35 & 1.33 & 1.32 & 1.30 & 1.28 \\
\hline LSF & 0.95 & 0.92 & 0.94 & 0.92 & 0.89 & 0.86 & 0.83 & 0.77 & 0.75 & 0.70 & 0.69 \\
\hline AR & 1.70 & 1.63 & 1.62 & 1.65 & 1.63 & 1.53 & 1.55 & 1.61 & 1.66 & 1.62 & 1.64 \\
\hline SR & 2.21 & 2.49 & 2.62 & 2.74 & 2.79 & 2.96 & 3.00 & 3.18 & 3.32 & 3.45 & 3.87 \\
\hline $\mathrm{C}_{3} \mathrm{~S}$ & 65.79 & 67.00 & 65.71 & 68.02 & 68.87 & 70.02 & 71.31 & 72.11 & 73.02 & 72.22 & 73.01 \\
\hline $\mathrm{C}_{3} \mathrm{~A}$ & 6.50 & 6.21 & 6.00 & 5.65 & 6.32 & 6.08 & 5.97 & 5.31 & 5.57 & 4.10 & 5.55 \\
\hline $\mathrm{C}_{4} \mathrm{AF}$ & 9.05 & 8.53 & 8.32 & 8.21 & 8.03 & 7.65 & 7.54 & 7.31 & 6.66 & 6.32 & 5.75 \\
\hline
\end{tabular}

This is also in line with what Adesanya and Raheem (2009b) and Taylor (2004) reported, which stated that high magnesia content is not desirable in cement because it causes unsoundness. Magnesium oxide $(\mathrm{MgO})$ contents of the NSHA blended cement is in the range of 2.33 to 3.37. All the blended cement produced satisfied the maximum of $6.00 \%$ magnesium oxide content requirement for both Type II and Type IIA Portland cement specified by ASTM C 150:2000.

The minor compounds of $\mathrm{Na}_{2} \mathrm{O}$ and $\mathrm{K}_{2} \mathrm{O}$ are known as alkalis. These values increase from $5 \%$ to $50 \%$ replacement. However, the values of $\mathrm{K}_{2} \mathrm{O}$ for all the NSHA blended cements are higher than the control and than the value reported by Adesanya and Raheem (2009b) which ranged between $0.36 \%$ and $0.83 \%$ for $2 \%$ and $25 \%$ replacement, whereas the values of $\mathrm{Na}_{2} \mathrm{O}$ are lower ranging between $0.12 \%$ and $0.03 \%$ for $5 \%$ to $50 \%$ replacement, respectively. Higher alkalis in cement are undesirable as it causes damage to kiln and attack reinforced concrete as reported by Taylor (2004). It also results in alkali - silicates reaction (Dabai et al., 2009). The sulphur trioxide present in all the blended cement as presented in Table 3 are higher than that of the control. This is in agreement with Adesanya and Raheem (2009b), having a report of all sulphur trioxide of CCA blended cements to be higher than the control. According to Singh (2000), high sulphate content in cement should be from gypsum, which is one of the raw materials in blended cements, and which is used in controlling setting time. Neville (1986), stated that the cement product with high content of sulphate are acid resistant while on the other hand, Taylor (2004) opined that small quantity of sulphate present in cement prevent the formation of Tricalcium aluminate $\left(\mathrm{C}_{3} \mathrm{~A}\right)$. Hence, all the blended cements satisfied the maximum of 3.00\% sulphur trioxide content requirement for Type II and Type IIA Portland cement specified by ASTM C 150:2000.

The lime saturated factor (LSF) for NSHA blended cements with 5\% - 50\% ash replacements ranged from 0.92 to 0.69 making it lower than the control value of 0.95 indicating that as the percentage replacement of the ash is increasing, the LSF content of the blended cements decreases. The free lime content also decreases as the percentage replacements of ash increases. This is in line with the report of Adesanya and Raheem (2009b) which reported a decrease in LSF for CCA blended cement. With reduced lime, the free lime content is lower, thus enhancing the soundness of cement (Adesanya and Raheem, $2009 b$ ). Consequently, all the blended cements produced satisfied the limiting value of $2-3 \%$ of free 
lime content specified by NIS 439: 2000. The silica ratio (SR) for all blended cements produced with 5 to $50 \%$ ash replacements ranged between 2.49 and 3.87. This corresponded with Adesanya and Raheem (2009b) which reported increase in SR content for CCA blended cements from 2.69 to 2.96 between 2 $25 \%$ replacements of CCA. Burning becomes extremely easy for silica ratio below 2:1 but excessive liquid phase and low strength cement is obtained. However, if the SR reaches a value up to 3.0, then high strength cement is achieved. Meaning the higher the SR, the higher the strength obtained. SR above 3.0 indicates no clinkerisation takes place at all (Amin and Ali, 2010). However, all blended cements produced satisfied the recommended limit value of $5 \%$ by NIS 439: 2000. It can thus be affirmed that all blended cements produced satisfied the limiting values recommended by the available standards for each of the chemical compositions.

\section{Consistency}

The consistency of NSHA blended cement increased as the percentage substitution of ash increases from $5 \%$ to $50 \%$ as presented in Table 4 . The control has the lowest consistency of $24.50 \%$. The consistency results for $5 \%$ to $50 \%$ range from $25.50 \%$ to $28.80 \%$ as the NSHA replacement increases. The increase was due to a reduction in cementitious binder in the mixture as the NSHA content increases (Ramsharath et al.,, 2017).

\section{Setting time}

Figure 1 show the initial and final setting time for NSHA blended cements. From Figure 1, the initial and final setting time of NSHA blended cement increased from 45 to $72 \mathrm{~min}$ and 135 to $235 \mathrm{~min}$, respectively, when the percentage replacement of NSHA increased from 5\% to 50\%. This is in agreement with the findings of Adesanya and Raheem (2009), Abdullahi (2006) and Chowdury, Maniar, and Suganya (2015). All the blended cements satisfied the NIS 439:2000 requirement of 45 min minimum initial setting time and maximum of 10 hours final setting time.

Table 4: Consistency and setting time of blended cement

\begin{tabular}{cc}
\hline NSHA (\%) & $\begin{array}{c}\text { Consistency } \\
(\mathrm{mm})\end{array}$ \\
\hline 0 & 24.50 \\
5 & 25.50 \\
10 & 25.90 \\
15 & 26.25 \\
20 & 26.40 \\
25 & 26.75 \\
30 & 27.25 \\
35 & 27.55 \\
40 & 28.05 \\
45 & 28.50 \\
50 & 28.80 \\
\hline
\end{tabular}

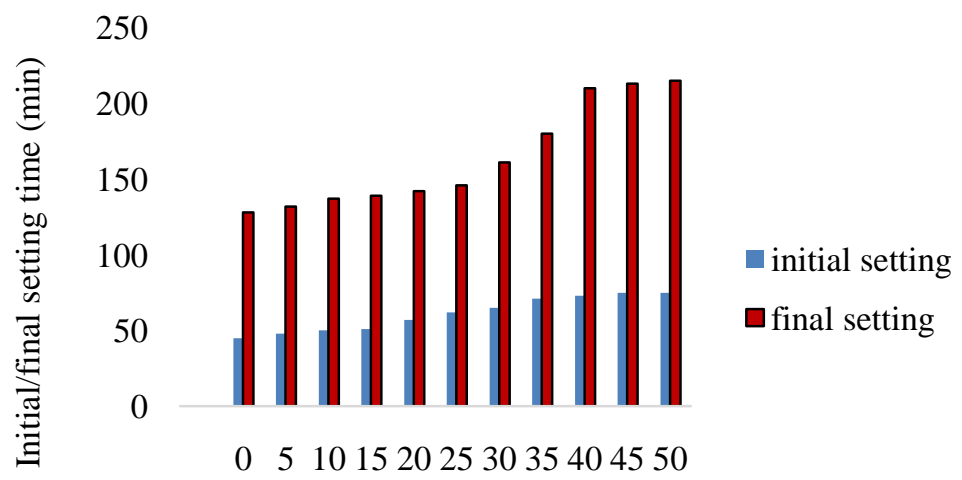

Percentage replacement of NSHA $(\%)$

Fig. 1: Effect of NSHA replacement on initial and final setting time of blended cement

The variation of setting time with percentage replacement of NSHA blended cements shows that both the initial and final setting time increased as their NSHA contents increased, hence, the hydration process is slowed down as a result of this. The slow hydration means low rate of heat development, which is one of the notable characteristics for which pozzolan contents are known to exhibit. This is of great importance in mass concrete construction where low rate of heat development is very essential as it reduces thermal stresses. As the initial and final setting times increase with increase in NSHA content, the exothermic 
reaction between cement and water result into liberation of heat and evaporation of water and eventually hardening of the paste.

The rate of reaction and quantity of heat liberated reduce with increase in the percentage of NSHA content, eventually leading to late stiffening of the paste. However, all the NSHA blended cement satisfied the maximum requirement of $375 \mathrm{~min}$ by ASTM C150:2002 for final setting time and also satisfied the NIS 439:2000 requirement of 45 minutes minimum initial setting time. However, it was observed that the NSHA blended cement for $45 \%$ and $50 \%$ replacements were not viable for reading as there was little cementitious material present in it.

\section{Heat of hydration}

The heat of hydration of all the NSHA blended cements for six hour duration is as presented in Figure 2. It was discovered that the temperature of the control sample increased consistently while all others showed constant temperature for some hours before showing slight changes in temperature. This indicates that the control sample generated more heat of hydration at early stage while all other NSHA blended cements produced low heat of hydration at early stage. It was also discovered that the more the percentage replacement of the ash increased, the more the heat of hydration of the blended cement decreased.

In concreting works during winter, heat of hydration prevents the capillary moisture in the concrete from freezing which is of great advantage. Hence, rapid hardening Portland cement which produces more heat is useful while low heat Portland cement is better suited for mass concreting in summer (Shetty, 2005). Hence, since heat produced by NSHA blended cement reduces with increase in ash replacement, it is suitable for use in the production of mass concrete works in summer.
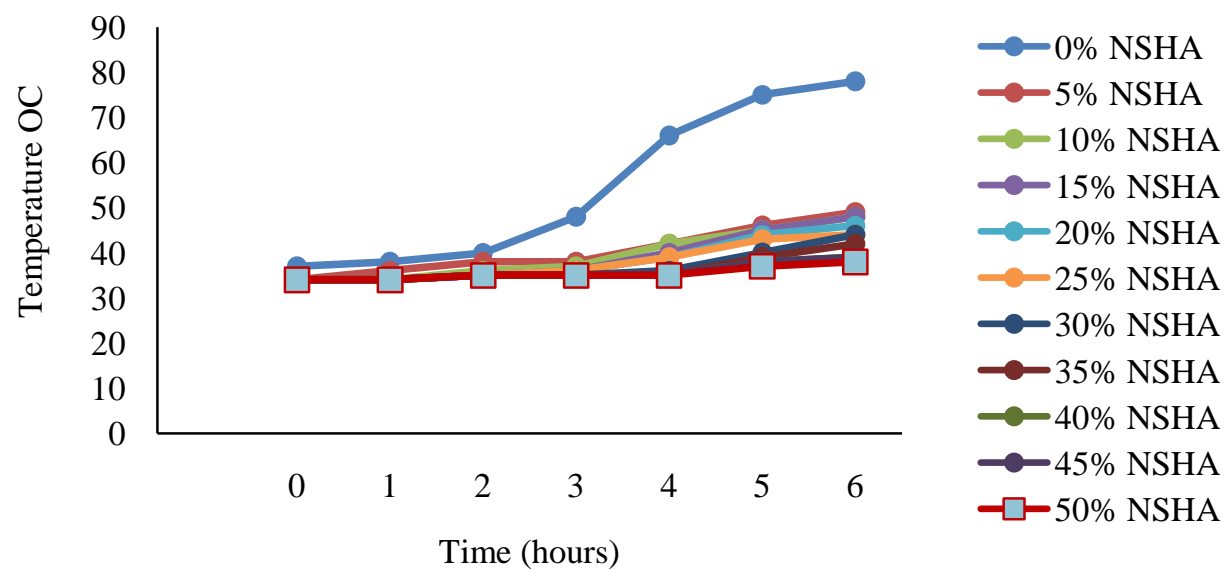

Fig. 2: Heat of hydration of NSHA blended cement

\section{Conclusions}

From the study, the following conclusions were made.

(i) NSHA is a suitable material for use as a pozzolan, since it satisfied the requirement for such a material by having a combined $\mathrm{SiO}_{2}, \mathrm{Fe}_{2} \mathrm{O}_{3}$ and $\mathrm{Al}_{2} \mathrm{O}_{3}$ of more than $70 \%$.

(ii) The addition of NSHA in blended cement increased marginally the percentage of $\mathrm{SiO}_{2}$ and $\mathrm{FeO}_{3}$ and decreased slightly that of $\mathrm{Al}_{2} \mathrm{O}_{3}$ and $\mathrm{CaO}$.

(iii) NSHA blended cements produced has higher setting times than the control. Hence, it is most applicable where low rate of heat development is required especially in mass concrete work and dam construction.

Based on the findings from this study, the following recommendations are made:

This study established the possibility of the production of NSHA blended cement and the use of NSHA blended cement where low heat cement is required, especially in mass concrete production. 


\section{References}

Abdullahi, M. (2006), Characteristics of wood ash/OPC concrete. Leonardo Electronic Journal of Practices and Technologies. 8: 9 - 16

Adesanya, D.A. and Raheem, A. A. (2009), Development of Corn Cob Ash Blended Cement. Construction and Building Materials, 23, 347 - 352

Adesanya, D.A. and Raheem, A. A. (2009b), A study of the workability and compressive strength characteristics of corn cob ash blended cement concrete. Construction and Building Materials, 23 (1): $311-317$

Amin, N. and Ali, K. (2010), Chemical Analysis and Comparison of Ordinary Porland Cement of Khyber Pakhtoo Khwa Pakistan. Chemical Engineering Research Bulletin. 14: 45 - 49.

ASTM C 150 (2002), Standard Specification for Portland Cement. Annual book of ASTM Standards (Revised Edition). 4(2), $1-7$.

Anwar, M., Miyagawa, T., and Gaweesh, M. (2001), Using Rice Husk ash as a Cement Replacement Material in Concrete. In the Proceedings of the 2001 First International Ecological Building Structure Conference, 671- 684.

BS EN 197-1 (2000). Composition, Specification and Conformity Critaria for Common Cements.

British Standard Institute, 389 Chiswick high Road, London, W4 4AL.

Dabai, M. U., Muhammad, C., Bagudo, B.U. and Musa, A. (2009). Study on the effect of Rice Husk Ash as cement Admixture. Nigeria Journals of Basic and Applied Sciences, 17 (2), 252 - 256.

Day, L. R. (1990). Pozzolans, for use in Low- Cost Housing, A State of the Art Report prepared for The International Development Research Centre Ottawa, Canada.

Fetra, V. R. (2011), Application of RHA'S Pozzolanic Properties in the making of CEB. International Journal of Sustainable Construction Engineering and Technology, 2(2), 32 - 36.

Ibiwoye, E. O. (2015). Investigation of Neem Seed Husk Ash as Partial Replacement for cement in Concrete, unpublished. M. Tech. Dissertation, Ladoke Akintola University of Technology (LAUTECH), Ogbomoso, Nigeria.

Illston, J. M. and Domone, P. L. J. (2001). Construction Materials; Their Nature and Behavior, First Edition, Taylor \& Francis e- Library.

Kartini, K., Mahmud, H. B. and Hamidah, M. S. (2006). Strength Properties of Grade 30 Rice Husk Ash Concrete. $31^{\text {st }}$ Conference on "Our World in Concrete and Structures, Singapore.

Khandaker, M. and Anwar, H. (2003), Blended Cement using Volcanic Ash and Pumice. Cement and Concrete Research, 33, 1601-1605.

Lea, F.M. (2005).The Chemistry of Cement Concretes, (Revised Edition). Edward Arnold Publishers Ltd.

Ngab, A. S. (2002). Concrete Technology in Developing World, Proceedings, $7^{\text {th }}$ International Conference on Concrete Technology in Developing Countries. Kuala Lumpur, 19 - 32.

Nuruddeen, M. M. (2014). Thermal Analysis of Cement Paste Partially Replaced With Neem Seed Husk Ash. International Journal of Scientific \& Engineering Research, 5(1): 1101 - 1105.

Olusola K. and Adesanya D.A. (2004). Public Acceptability and Evaluation of Local Building material housing construction in Nigeria. Build Environment 1, 83-89

Ramsharath, M, Gopinath, S. and Balaji, E. (2017). Study on Neem Seed Husk Ash as replacement material for Cement. Journal of Industrial Pollution Control $\quad 33($ S2):1285-1287. www.icontrolpollution.com. Retrieved on $29^{\text {th }}$ Jan. 2018.

Shetty, M. S. (2005). Concrete Technology, (Revised Edition), Ram Nagar, New Delhi, S.Chand.

Taylor, H. F. (2004), The Chemistry of Cements (Vol. 1). Academic Press, New York. 